\title{
Texas Today: A Sea of the Wrong Grasses
}

Forrest S. Smith

"I $\mathrm{n}$ the '60s when I bought this place and moved here from Houston, we had so many quail that you didn't even need a bird dog to find them," mused my 85-year-old hill country neighbor. "Then," he paused, his satirical glance drifting toward the mantle to a dust-covered 20-gauge double-barreled shotgun and a faded John Cowan Print of a quail hunt on a shin oak mountaintop of the Texas hill country, "by the early' 80 s, the quail were gone."

"Well," I interjected in a smug biologist's refrain, "what changed?"

"Hell, I dunno, but just before that time everybody planted all the maize fields to coastal (bermudagrass), and that damn KR bluestem came in from the highway when they redid it."

"I'll bet that's part of it," added the old man.

What ran through agronomist Nick Diaz's mind on a hot, dry Gulf Coast summer day in 1939, when he first laid eyes on the maroon, glistening seedheads of Dichanthium annulatum growing in a King Ranch pasture, was probably a lot different than what raced through mine on April 26, 2009. As the one who first noticed the accidentally introduced African grass, and the one who helped select, increase, and release what would come to be known as Kleberg bluestem, Mr. Diaz had high hopes for transforming dried up, grass-poor ranges into lush seas of grass. He probably envisioned pastures full of fat cattle and a buffered annual bonus check, courtesy of this grass that could grow so well, and so aggressively, in the hellish windblown sands and cracked black clays of the Wild Horse Desert of south Texas.

Today's biologists look upon Kleberg bluestem, and its African, Asian, and Australian grass cousins brought to Texas, with a nauseating suspicion of an ecological nightmare. It is akin to a viral pandemic, swallowing up chunks of what few can accurately describe with words, few thoroughly understand, but what used to be waves of bluebonnets and paintbrushes in the spring, crimson stands of native prairie grasses in the fall, and carpets of yellow flowers interspersed by funny looking grasses whose seeds stick in

Ecological Restoration Vol. 28, No. 2, 2010

ISSN 1522-4740 E-ISSN 1543-4079

(O2010 by the Board of Regents of the University of Wisconsin System.

Open Access: Creative Commons license by-nc-nd 3.0 socks and shoestrings. The native Texas landscape is disappearing before our eyes, under a sea of the wrong grasses.

What ran through my mind on April 26, 2009, when I saw those maroon seedheads blowing in the breeze alongside U.S. 183 was much different than what Nick Diaz must have pictured in 1939. I wondered aloud what the hell a grass that I work to rid south Texas of on a daily basis was doing on a highway right-of-way in one of the most rural counties of central Texas a hundred miles from where it ever grew in the past. In my 20 years of being a plant maniac, and my father's 40 of ranching, we'd never seen it here before. Scarier still, those ripe seeds, like a pandemic land virus, ended up washing down two different creeks in the six inch rain we had two days later. I didn't envision a pasture full of cattle, but in my mind's eye, I can imagine one further void of quail, with fewer wildflowers and all the things that make the native Texas landscape special.

I bet that my father and I will see more Kleberg bluestem again in central Texas, and I suspect that my grandchildren will see more of it than I care to imagine. If action isn't taken now, there's a good chance that what's left of the Texas rural landscape will be a sea of the wrong grasses.

\section{Exotic Grasses, Economics, and Ecologists}

Urban sprawl be damned, another threat, quieter and of drastically underestimated importance to native habitats and wildlife, is rampaging unchecked across the Texas landscape. Past generations of Americans thrived on the beef and spoils produced in part by the greatest period of range grass experimentation and introduction known to mankind. Throughout the 1900s, and even still today, Texas ranchers and agronomists were and are leaders in the practices of importing and planting "improved" exotic range grasses.

Why we have them is as long a story as why south Texans vote Democrat, in part just because. Old standby statements like "buffelgrass is the grass that saved south Texas" or "I wouldn't dare ranch in Texas without exotic grasses" echo from cattlemen of my grandfather's generation. Many still say this today, while cashing $\$ 15$ per acre hunting lease payments, griping about $\$ 3$ per acre cattle proceeds, and continuing to conduct land management activities wholly for cows. In contrast, progressive outfits like the King, Temple, and Killam Ranches don't dare plant more exotic grasses and require oil companies to reseed disturbed sites only with natives. Granted, some of these ranches used to plant exotic grasses for cattle forage. But in the past 
few years, as wildlife recreation increased in value and the uncontrollable spread of these grasses became apparent, they stopped and made a philosophical sea change in their management styles.

To lament the intentional planting of exotic grasses or the happenstance introduction of others in bags of dirty seed brought to Texas from Australia and other parts of the world in the early 1900s is of no use to today's wildlife. Finger pointing and stubbornness won't provide habitat to the last bobwhite quail on a Gulf Coast Plain pasture or hill country mountainside. As Rachel Carson (1962) in her environmentally supercharged prose so eloquently put it, "like the resource it seeks to protect, wildlife conservation must be dynamic, changing as conditions change, seeking always to become more effective." By all science known to us today, exotic grasses are destroying what little bit of great native wildlife habitat we have left. Spread and dominance of exotic plants such as these is second only to complete destruction of habitat as the most troubling wildlife conservation topic worldwide (Wilson 1992). Stepping on toes and pointing fingers about the wisdom of past exotic grass introduction to Texas will certainly be ineffective, but a radical change in land management in our state, and cessation of practices that further spread exotic grasses, might be good changes for our generation. The time is now for Rachel Carson's suggestion of becoming more effective, before we have no real native habitats left.

\section{Yesterday's Exotic Grass Solution and Today's Problem}

Exotic grasses cause problems to wildlife, native plants, and the natural ecological cycles of any area in which they occur. Texas today is far different from Texas when these plants were introduced. In the early 1900s, Texas was rural, with small farms surrounded by large contiguous ranches, and probably fewer paved roads statewide than today exist in Harris County (surrounding Houston) alone. A typical ranch was stocked to the gills with cattle, supplemented with sheep, goats, or horses, and was running out of grass long before the first exotic buffelgrass (Pennisetum ciliare) seed was planted. Soil erosion and clouds of dust would've made an ecologist of the time write a much different article than this, had the economy permitted such luxury. Native Texas rangelands and Texas grazing styles of the time didn't mesh well with one another. In addition, renovating and revitalizing fires that had sustained and promoted many native plants and habitats had long been suppressed; coupled with the everyday grazing by cattle stocked too heavily in pastures recently rimmed with barbed wire, the situation made for a countryside running low on grass and shorter on dollars.

In the early 1900s, King Ranch obtained Rhodes grass (Chloris gayana) seed from South Africa. What was a novel idea and a trial to increase forage in overgrazed pastures led to a program that, like many other King Ranch ideas, worked and worked well. Rhodes grass almost completely died out in south Texas in later years owing to an accidental exotic insect introduction, but the potential benefits in forage production by exotic grasses were by then wellknown. Soon, federal and state agencies had joined the effort, and by the 1950 s every grass from every part of the world that a cow would eat was being evaluated or planted across Texas. Old Soil Conservation Service land management plans included the common recommendation to chain, plow, or grub brush and "seed to yellow (King Ranch) bluestem" (Bothriochloa ischaemum) or "seed to buffelgrass." Releases of exotic grass products from agencies to producers bore the proud names of their developers, like King Ranch and Kleberg bluestems. Literally hundreds of thousands, if not millions of acres of the Texas landscape have been planted to these grasses, principally Rhodes grass, Old World bluestems (Bothriochloa and Dichanthium spp.), buffelgrass, and Bermudagrass (Cynodon dactylon). Conservation efforts like the Conservation Reserve Program resulted in more exotic grasses being planted than most care to acknowledge. Other countless acres of overgrazed native rangelands were subsequently invaded by the ecologically unchecked spread of these grasses, or through accidental dispersal of seeds by livestock, ranchers, and equipment. Some of the grasses brought to Texas stayed where they were put; Rhodes grass is not much of a problem today, and Kleingrass (Panicum coloratum), a later introduction, usually behaves itself. Others like guineagrass (Urochloa maxima) and Lehmann lovegrass (Eragrostis lehmanniana) were planted here and there, but also got loose accidentally. Ask Rio Grande Valley birders what they think of guineagrass these days, or a west Texas rancher what Lehmann lovegrass is good for. Neither of these exotic grasses suits the needs of today's users of the landscape. Guineagrass suppresses plant diversity so that birds avoid areas infested with it, and Lehman lovegrass is at best a poor forage that chokes out better grasses.

To the livestock producers of last century, many exotics were miracle grasses; they established easily, grew aggressively, and took abusive stocking rates in stride. Wildlife, as an afterthought, was generally thought to have benefitted from these grass introductions, as some ground cover was obviously better than none. An environmental priority of the time, the nationwide soil conservation effort had been largely accomplished with their use. Obviously, wildlife weren't the concern then as they are today, despite the eloquent writings of Aldo Leopold (1949) and other farsighted conservationists. Annual lease payments of $\$ 15$ per acre for hunting access to ranches weren't even a dream to most landowners, and it's rare that someone's conservation ethic completely trumps the need for a roof over their head or food on the table. But what was a winning necessity in 
economic terms for Texas agriculture and a quick fix to decades of abusive land management is now rapidly turning into ecologists' and wildlife biologists' worst nightmare. Wildlife and plant scientists are reporting a stunning truth about just how destructive exotic grasses are to wildlife and native habitats. Bird and insect numbers plummet on exotic grasslands, exotic grasslands have lower plant species diversity, and exotic grass abundance appears to be increasing across our state. Many suggest that the catastrophic wildfires in recent years are due in large part to the current sea of exotic grass. Recent fires such as 2008's 50,000 acre inferno that burned south Texas' Chaparral Wildlife Management Area are a scary reality in the state, facilitated in part by the fact that "exotic grasses are now a major part of the understory," according to Texas Parks and Wildlife Department's Executive Director Carter Smith (TPWD 2008).

What's even more concerning than rampant fires and biological data staring us in the face is that current techniques for restoring landscapes infested with exotic grasses, or efforts to remove them from an area, fail miserably. A common thread in many short-duration research projects dealing with exotic grass control is the oft-ending refrain that the exotic grasses eventually reinvaded and dominated the site by the end of the project. Current failures can be blamed on the sad reality of the scope of the problem; many restoration efforts are nothing more than small islands of effort in an otherwise expansive sea of more aggressive exotic plants. Continual seed rain and unknown seedbank ecology of exotic grasses doom many restoration efforts from the start. Even if native plants can be reestablished, they are quickly overwhelmed and outcompeted by reinvading exotic grasses.

The problem worsens continually because well-established seed sources along highways are mowed less and less frequently and fewer cows exist on most ranches to prevent uninhibited seed production by exotic grasses. Ironically, today's land use, even by well-intentioned stewards of wildlife who defer livestock grazing on historically overgrazed ranges to facilitate natural restoration, may exacerbate the exotic grass problem in heavily invaded systems. Collectively, the increase in source populations provides evidence of "environmental swamping" by exotic grasses. Asked recently by a land manger what would keep guineagrass and Kleberg bluestem from completely overtaking his ranch, my dejected answer was, "I don't know."

In short, Texans who treasure and now financially depend on wildlife and the native landscape have a big problem, and they don't yet know how to fix it.

\section{A Changing Landscape}

How exotic grasses, native plants, and wildlife existed in equilibrium for decades is perplexing. Perhaps ecological thresholds weren't crossed by the amount of exotic grasses in 1960 or 1980; perhaps cattle still made enough money that most Texas pastures still had a fleet of exotic grassharvesting cows working around the clock. Maybe even more importantly, a lot more of Texas didn't have a road, gas pipeline, power line right-of-way, or other disturbance facilitating dispersal of exotic grass seed. Hill tops in the big country of west Texas, or the tallgrass prairies of south Texas, didn't have so much as a road through them, much less 200-turbine wind farms. Maybe even the climate changed along the way. As with most ecological phenomena, the reason is probably a combination of all these things. The harsh reality for many ranching operations is that cattle are no longer king and people pay money and buy land to watch birds, shoot quail, and see wildflowers. Most cattlemen can't afford to buy property in the Texas Hill Country for $\$ 4,000$ per acre. Hunting and other recreational pursuits drive today's land prices, not cattle production. Wildlife and outdoor recreation are large, but often overlooked, industries that now sustain rural economies in Texas and entertain city dwellers on weekends. These industries don't benefit from seas of exotic grasses the way cattlemen did.

Exotic grasses like buffelgrass, Lehmann lovegrass, guinea grass, Bermudagrass, and Kleberg, King Ranch, and Angleton (Dichanthium aristatum) bluestems have one annoying thing in common to the wildlife or plant biologist: they typically don't play well with other plants. These grasses grow in a way that excludes most other plants, either by their physical stature and growth rate or, as is just now being discovered, by altering their habitat and the soils they invade so that no other plant will be able to thrive there. With the elimination of a few native weeds, wildflowers, and bunchgrasses in a pasture overcome with an exotic grass, comes elimination of a few bugs that live only on a single wildflower, a few weed seeds, and a few quail nesting sites. With a few less flowers, bugs, weed seeds, and bunchgrasses there tend to be a few less quail. Quail don't like places with no flowers and no bunchgrasses. No, they aren't botanists, but they do like to eat and have to nest successfully to sustain their populations. Minus just a few quail, landowners in many parts of the state today might not have any left. A result of this in south Texas could be the loss of that annual lease payment for hunting rights; that's big money in an area such as rural Jim Hogg County, where several hundred thousand acres are leased to quail hunters in a given year.

Biologists think this cascading effect may be occurring with many native Texas animals and plants. Grassland birds and many ground-dwelling mammals and reptiles 
also show alarming population reductions at the same time that exotic grasses have increased. Exotic grasses are the principal threat to many endangered plants in Texas, like slender rush-pea (Hoffmannseggia tenella), south Texas ambrosia (Ambrosia cheiranthifolia), or Zapata bladderpod (Lesquerella thamnophila). While much of this important biodiversity is becoming a rare sight in Texas, exotic grasses aren't. Unless you're lucky enough to visit one of the last big ranches in Texas, exotic grasses are the staple view, whether the venue be a highway roadside, urban alleyway, or rural farmstead.

Exotic grasses today are negatively influencing or invading what little of the native landscape we have left. In south Texas, for instance, almost any oil rig caravan, piece of mowing equipment, wind farm service truck, or hunting rig sports a healthy collection of buffelgrass and Kleberg bluestem seeds in the grille, ready to be deposited on the plethora of new drilling-site roads, wind farms, highway rights-of-way, or gas pipelines dissecting the vanishing former expanses of native plants. Most experts agree that a big factor in many native habitats being overtaken by exotic grasses is the increase in disturbance and the incursions by wind farms, power lines, roads, and urban sprawl into formerly contiguous, unfragmented habitats.

Another undeniable cause is that many of these grasses are still being planted, and with greater efficiency and purpose than ever before. Buffelgrass is still probably the biggest rangeland seed crop sold statewide. Genetic and agronomic engineering of many exotic grasses has made them even more vigorous than they naturally were. Coldtolerant buffelgrass is one scientific accomplishment feared by many ecologists; luckily, these cold-tolerant cultivars have had only modest success in the buffelgrass market. Guineagrass is commercially disguised as "green panic grass" and frequently sold to unsuspecting consumers, who'd never consider planting guineagrass if it were labeled as such. Today's Bermudagrass cultivars possess downright scary adaptations for vigor and spread. As a result of federal Clean Water Act provisions designed to prevent soil erosion, the giant buyer of the grass seed market, the Texas Department of Transportation (TxDOT), is forced to plant exotics at the completion of a highway project if native seed is not immediately available in the necessary quantities. Mining companies include Old World bluestems in reclamation seed mixes for wildlife habitat on unsuspecting ranches because the seed is cheap. Landowners mistakenly plant buffelgrass seed to create better quail habitat, despite solid research findings in top scientific journals that areas infested with it support just half the quail of native plant communities (e.g., Flanders et al. 2006).

Unless changes in land-management mindsets are made, exotic grasses may no longer be one of the issues facing conservationists; they may well become the issue. The issue today is that landowners and agencies must change how they use the Texas landscape if they want to preserve natural landscapes. Some changes would be devastating. The still important cattle industry needs grasses like buffelgrass and bermudagrass to thrive; that use cannot realistically be compromised, but other careless ones can. State agencies such as TxDOT can stop planting exotic grasses on roadsides, ever. It may not be easy, and may take changes in how things have always been done, but most all agree it is feasible.

Landowners can put their foot down to oil and gas and energy giants who whine about the cost of restoring land with native plants after destructive exploration and petroleum production practices, and refuse to allow them to plant cheaper exotic grass seed. Few people can realistically be sympathetic to oil companies over the difference in restoration costs of a couple hundred dollars an acre on drilling sites that produced thousands of dollars of profits each day for the most profitable companies in the world.

The wisdom of fragmenting and dissecting thousands of acres of native habitat with environmentally friendly wind energy and accompanying transmission lines should also be examined with a view toward vegetation and ecosystem importance before we so readily fall head over heels for it. Hay production involving known problematic exotic grasses like Kleberg bluestem should cease, not by regulations but through education. Many a rancher inadvertently plants his ranch with Kleberg bluestem by feeding cheap trucked-in hay to cattle.

A billboard proposed by one agency all too aware of this problem is to read "hello buffelgrass, goodbye quail." This effort is part of an educational campaign to convince Texans not legislatively, but sensibly, to think twice about their actions involving exotic grasses. Along with educating the masses and protecting the few relict native sites we have left, researchers also need to devise better solutions to improve the widespread problematic areas that exist today and slow the exotic grass invasion. It will take this multipronged approach to make a difference.

\section{Turning the Exotic Grass Tide}

Smoke from the fire of the "patch" burn in a remote pasture of a 13,000 acre La Salle County ranch no doubt caused a few calls to the Cotulla volunteer fire department. Given 2008's uncontrollable 50,000 acre buffelgrass-assisted inferno in the area, who can blame the callers? But this small fire, a prescribed one, was over quickly enough that nobody got too worried about it. A herd of Mexican steers will be camped out on the burned area in a few days, tromping through the ashes to eat the fast-emerging, tender sprouts of buffelgrass and Kleberg bluestem. The intent here is not T-bones and hamburgers, but to kill or suppress the exotic grasses so native plants can once again grow here. The practice goes against all 
logic of Range Management 101, which says burned areas should be deferred from grazing for long periods after the fire to let grass regrow. That mindset stems from cattle production but is rapidly changing in Texas and elsewhere. The difficulty of exotic grass management in south Texas requires some new mindsets, and this pyroherbivory, as scientists call it, is just that. Wildlife researchers from the Caesar Kleberg Wildlife Research Institute (CKWRI) track habitat use by radio-collared quail in the vicinity of the treatments to evaluate the project, and they couldn't care less about how many pounds of beef are produced.

In another pasture of the ranch, a patchwork of herbicide, native seeding, and soil disturbance treatments is being evaluated to diversify the exotic grass-dominated landscape. A neighboring landowner is voluntarily mimicking the same treatments to assist researchers. It's an understatement to say that ranch objectives have changed in this area and elsewhere in Texas. The landowners fund this research because they want quail, and they used to have a lot of them before buffelgrass and Kleberg bluestem took over the landscape. Ranch manager and former CKWRI student Mike Hehmann spends countless hours each day struggling to grow wildlife out of exotic grasses. This project is overseen by range and wildlife scientist Dr. Tim Fulbright, who's long been maligned by exotic grass seedsmen, despite his A\&M Regents Professor credentials, for questioning years ago the ecological wisdom of exotic grass introductions. This research and other projects like it are being done across Texas by a new breed of wildlife and range scientist, like CKWRI Ph.D. student Eric Grahman, who frequently ends presentations about the La Salle County project with the chilling point "that losing all those wildflowers, and all those native grasses-all that biodiversity that makes the Texas landscapes special—would be very sad?'

\section{Treading Water in the Sea of Exotic Grasses}

Programs like "South Texas Natives" at CKWRI, the Lady Bird Johnson Wildflower Center, the North Texas Ecotype Project, and a restoration program at the Borderlands Research Institute in west Texas are working to turn the tide of this sea of exotic grasses and make restoration attempts more successful. These entities, units of state universities, are already in place to tackle this issue. Agencies like Texas Parks and Wildlife Department, the USDA's Natural Resources Conservation Service, and TxDOT are rapidly becoming aware of exotic grass problems and contribute greatly to the effort. Collectively, these organizations are doing their best to find solutions, albeit with scant resources compared to the severity of the issue.
Private landowners want solutions as well; recent surveys rank exotic grasses as a primary land management concern in Texas. Landowners support and provide research sites for efforts to convert exotic grass-dominated areas back to native plant communities, and to study the effects of exotic grasses on economically important wildlife. Many Texas landowners have made a fundamental change in their view of exotic grasses, and become more effective managers of their lands in today's conditions as a result. It's time that change happened on an even larger scale.

What we, as scientists and practitioners, must do is present our issue better. Studies of exotic grass management and native landscape restoration aren't sexy topics like the animals that depend on them. It's hard to take a picture of a swath of exotic grasses and get the point across to a mostly urban audience or an Austin legislator. Multidisciplinary, long-term support for efforts to develop and promote native plants and find ways to manage exotic grasses is vital to success in the exotic grass battle. One such effort conceived by landowners to address this statewide ecological nightmare got some legs in the Texas Legislature last session, but it didn't last. It won't be until someone in Austin's granite halls makes exotic grasses and loss of our native landscape a priority, and fights for the resources to address it, that scientists will be able to effectively address exotic grass invasion and restoration on a meaningful level. Exotic grasses are the conservation elephant in the room, and elephants take big guns to bring down.

These grasses aren't just a Texas problem. Invasive species such as these grasses know no political boundaries, and formulating a model for how to address this issue here, now, in the lion's den, so to speak, would be useful for coming generations elsewhere who will be affected by this pandemic. Rampant exotic grass invasions in Mexico and Arizona are perfect examples of neighbors with the same dire issues, caused by some of the same wrong grasses. The threat to continental biodiversity and ecosystem function by seas of the wrong grasses should not be underestimated.

Our grandchildren may one day muse about the loss of the native landscape's beauty from the tides of the sea of wrong grasses, the way my neighbor does about hill country quail. As ecologists and restorationists, it's time that we do all we can to prevent that from happening. The action that enables that change will be a combination of long-term research and efforts that somehow convince everyday citizens and, in turn, policymakers that this is an aspect of their existence they should care deeply about. Without intervention and a rapid change in this generation's management of natural resources by landowners, energy producers, and state agencies, the native Texas landscape-the fundamental thing that makes Texas, Texas - will be a victim of exotic grasses and a sad part of our state's rich history. 


\section{Acknowledgment}

This is Caesar Kleberg Wildlife Research Institute Manuscript No. $10-120$

\section{References}

Carson, R. 1962. Silent Spring. Boston: Houghton Mifflin.

Flanders, A.A., W.P. Kuvlesky Jr., D.C. Ruthven III, R.E. Zaiglin, R.L. Bingham et al. 2006. Effects of invasive exotic grasses on south Texas rangeland breeding birds. The Auk 123:171-182.

Leopold, A. 1949. A Sand County Almanac. New York: Oxford University Press.

Texas Parks and Wildlife Department (TPWD). 2008. Wildlife, infrastructure spared by massive fire on Chaparral WMA. News release, March 21. www.tpwd.state.tx.us/newsmedia/ releases/?req $=20080321 \mathrm{a}$

Wilson, E.O. 1992. The Diversity of Life. Cambridge: Harvard University Press.
Forrest S. Smith is South Texas Natives Project Coordinator for Caesar Kleberg Wildlife Research Institute at Texas A\&M University-Kingsville, 700 University Blvd MSC 218, Kingsville, TX 78363,361/593-4525, forrest.smith@tamuk.edu. 